\title{
FUNGSI MANAJEMEN TERHADAP PENDIDIKAN ISLAM
}

\section{BESSE RUHAYA}

Universitas Islam Negeri Alauddin Makassar

besse.ruhaya@uin-alauddin.ac.id

\begin{tabular}{|c|c|c|}
\hline Received & Revised & Accepted \\
\hline 10 Januari 2021 & 10 Februari 2021 & 28 Maret 2021 \\
\hline
\end{tabular}

\section{FUNCTION OF MANAGEMENT TO ISLAMIC EDUCATION}

\begin{abstract}
The management function of Islamic education is very important as well as the management function in education in general. Where the management of Islamic education orientation Islamic educational institutions managed by Islam also to achieve the objectives of Islamic education effectively and efficiently. Experts differ in formulating the management process, but in essence there are several similarities that include four management functions that must be considered, namely Islamic education planning, Islamic education organizing, implementation of Islamic education, and supervision of Islamic education. By paying attention to the four functions of education management above, it is expected to improve the overall quality of education.
\end{abstract}

Keywords: functions, management, and Islamic education.

\begin{abstract}
Abstrak
Fungsi manajemen terhadap pendidikan Islam sangatlah penting, sama halnya terhadap fungsi manajemen pendidikan secara umum, dimana manajemen pendidikan Islam orientasinya lembaga pendidikan Islam yang dikelola secara Islami juga untuk mencapai tujuan pendidikan Islam secara efektif dan efesien. Para pakar berbeda dalam merumuskan proses manajemen, namun pada intinya terdapat beberapa persamaan yang mencakup empat fungsi manajeman yang harus diperhatikan, yaitu perencanaan pendidikan Islam, pengorganisasian pendidikan Islam, pelaksanaan pendidikan Islam, dan pengawasan pendidikan Islam. Dengan memperhatikan keempat fungsi manajemen pendidikan di atas, diharapkan dapat meningkatkan kualitas pendidikan secara keseluruhan.
\end{abstract}

Kata Kunci: fungsi, manajemen, dan pendidikan Islam.

\section{Pendahuluan}

Pada mulanya perkembangan manajemen hanya berkaitan dengan bisnis. Namun, seiring perkembangan waktu, manajemen digunakan dalam berbagai bidang, baik dalam bidang pendidikan maupun profesi lainnya. Pada masa sekarang ini, 
manajemen menjadi hal pokok dalam melaksanakan segala sesuatu bahkan hampir menjadi kebutuhan setiap orang. Berbagai kajian dilakukan dengan pokok bahasan utama yaitu manajemen. Bahkan kata manajemen dikaitkan dengan sesuatu yang bersifat metafisik, seperti manajemen qalbu yang diungkap oleh Abdullah Gymnastiar.

Konsep manajemen pendidikan apabila diterjemahkan pada pembelajaran dimana diartikan sebagai segala usaha atau tindakan pemimpin instruksional dalam sekolah/madrasah dan tenaga pendidik sebagai pemimpin pembelajaran di kelas sedemikian rupa dilakukan guna mendapatkan hasil yang baik dalam rangka mencapai tujuan program sekolah/madrasah dan juga tujuan pembelajaran. ${ }^{1}$. Hal itu berarti manajemen yang diterapkan di lembaga pendidikan merupakan suatu pengelolaan pada satuan unit pekerjaan yang telah diberi wewenang dalam pekerjaan tersebut yang bertujuan tercapainya proses pembelajaran dengan baik. Keberhasilan suatu lembaga pendidikan dalam menyelenggarakan pendidikan sangat tergantung terhadap kemampuannya dalam menerapkan fungsi-fungsi manajemen secara profesional. ${ }^{2}$ karena itu, maka efektifnya suatu pembelajaran dapat dicapai apabila fungsi-fungsi dalam manajemen, yakni fungsi perencanaan, pengorganisasian, penerapan, pengawasan dapat diaplikasikan dengan baik dan benar pada proses pembelajaran.

Berdasarkan uraian di atas, maka penulis mencoba meneliti tentang fungsi manajemen terhadap pendidikan Islam, dengan memberikan dua Batasan masalah yaitu bagaimana hakikat manajemen pendidikan Islam? Dan bagaimana fungsi manajemen pendidikan terhadap pendidikan Islam?

Berdasarkan penelusuran beberapa artikel maka ditemukan beberapa artikel yang terkait dengan pembahasan ini diantaranya "Fungsi Manajemen dalam Perencanaan Pembelajaran (Talibo, I. (2018), artikel ini memuat pentingnya manajemen untuk semua kegiatan baik kegiatan yang bersifat formal maupun nonformal, terutama dalam dalam hal pembelajaran yang harus dilakukan dan mengikuti tahapantahapan agar setiap kegiatan terlaksana dengan tertib dan lancar. Dalam pembahsan ini hanya membahas secara umum tentang fungsi manajemen perencanaan sedangkan dalam artikel yang kami buat kajiannya terhadap fungsi manajemen pada pendiidikan Islam. Artikel lain membahas " Implementasi Fungsi Manajemen Pendidikan terhadap Profesionalitas Guru (Sebuah Kajian Implementasi Sertifikasi Guru dalam Jabatan) (Anif, S. (2012), artikel ini membahas bahwa profesionalitas guru dapat dibentuk melalui empat kompetensi yang dipersyaratkan yaitu Kompetensi Profesional, Kompetensi Pedagogik, Kompetensi Kepribadian, dan Kompetensi Sosial. Dalam pembentukkan empat kompetensi, terutama bagi guruguru pasca sertifikasi harus dilakukan melalui reaktualisasi implementasi fungsi pendidikan yang benar yang meliputi perencanaan, pelaksanaan, pengorganisasian, pengawasan, dan evaluasi. Kompetensi profesional dan pedagogi yang menjadi

\footnotetext{
${ }^{1}$ (Sagala, 2017,h. 143)

${ }^{2}$ Fathul Maujud, “Implementasi Fungsi-Fungsi Manajemen Dalam Lembaga Pendidikan Islam (Studi Kasus Pengelolaan Madrasah Ibtidaiyah Islahul Muta'allim Pagutan)," JURNAL PENELITIAN KEISLAMAN, 2018, https://doi.org/10.20414/jpk.v14i1.490.
} 
kelemahan guru secara umum dapat di tingkatkaan melalui pendidikan dan pelatihan pengembangan profesi secara terstruktur, sistematik, dan berkelanjutan sebagai bentuk pembinaan keprofesian guru pasca sertifikasi secara berkesinambungan. Sedangkan dalam artikel yang saya akan bahas fungsi manajemen terhadap pendidikan Islam.

\section{Metode Penelitian}

Penelitian ini adalah penelitian kepustakaan (library research), yang bertujuan mengumpulkan data-data dan informasi yang berkaitan dengan fungsi manajemen dan pendidikan Islam melalui teknik pendekatan deskriptif kualitatif analysis. Adapun sumber data yang digunakan adalah buku-buku, atau jurnal yang berkaitan dengan permasalahan tersebut.

\section{Hasil dan Pembahasan}

\section{Pengertian Manajemen Pendidikan Islam}

Kata Manajemen diambil dari bahasa latin, yaitu "manus”, artinya "tangan"; dan agree artinya melakukan. Kemudian kata itu digabung menjadi kata kerja "manager"; yang artinya menangani. ${ }^{3}$. Selanjutnya dalam bahasa Inggris disebut managere dalam bentuk kata kerja to manage yang artinya mengatur, mengurus, melaksanakan atau mengelola. ${ }^{4}$. Selanjutnya dalam Kamus Besar Bahasa Indonesia, manajemen diartikan sebagai proses sumber daya dalam mewujudkan tujuan tertentu yang telah dikalkulasikan secara efesien dan efektif. ${ }^{5}$. Manajemen secara keilmuan baru dirumuskan pada akhir abad 18 atau sampai awal abad 19 Masehi. Tokoh yang pertama memperkenalkan manajemen secara keilmuan diantaranya Robert Owen (1771-1858) dan Charles Babbage (1792-1871). ${ }^{6}$

Adapun pengertian pendidikan menurut "Undang-Undang RI Nomor 20 Tahun 2003 tentang Sistem Pendidikan Nasional, Pasal 1 ayat (1)”, adalah usaha sadar dan terencana dalam mewujudkan suasana belajar dan proses pembelajaran agar peserta didik secara aktif mengembangkan potensi diri untuk memiliki kekuatan spiritual keagamaan, pengendalian diri, kepribadian, kecerdasan, akhlak mulia, serta skill yang diperlukan dirinya, masyarakat, bangsa dan negara. ${ }^{7}$

Berdasarkan uraian di atas, maka dapat dikatakan bahwa manajemen pendidikan bagaimana sumber daya pendidikan bisa mengelola suasana belajar agar peserta didik secara aktif mengembangkan potensi dirinya untuk memiliki kekuatan spiritual keagamaan, pengendalian diri, kepribadian, kecerdasan, akhlak mulia, serta ketrampilan yang diperlukan dirinya, masyarakat, bangsa dan negara dalam

\footnotetext{
${ }^{3}$ (Usman, 2008, h.8)

${ }^{4}$ (Shadily, 2013, h. 372)

${ }^{5}$ (Departemen Pendidikan dan Kebudayaan, 2005, 553)

${ }^{6}$ Kurniawan Saefullah Ernie Tisnawati Sule, Pengantar Manajemen (Jakarta: Kencana Prenada Media Grup, 2015).

${ }^{7}$ (Republik Indonesia, 2019, h. 3)
} 
mencapai tujuan pendidikan secara efektif dan efisien. Dalam hal ini manajemen pendidikan salah satu ilmu yang dipelajari bagaimana tingkah laku manusia dalam kegiatannya sebagai subjek dan objek.

Selanjutnya manajemen pendidikan Islam adalah suatu proses penataan secara Islami terhadap lembaga pendidikan Islam yang melibatkan sumber daya manusia untuk mencapai tujuan pendidikan Islam secara efektif dan efesien. ${ }^{8}$

Dari beberapa uraian di atas bisa disimpulkan bahwa inti dari manajemen pendidikan dan manajemen pendidikan Islam tersebut sama, yang membedakan hanya kultur dan orientasinya, dimana manajemen pendidikan Islam orientasinya lembaga pendidikan Islam yang dikelolah secara Islami juga untuk mencapai tujuan pendidikan Islam secara efektif dan efesien, objek pembahasan yang cukup komplek yang di dalamnya bercirikan Islam. Nah, Istilah Islam yang melekat pada kata manajemen bisa berupa Islam wahyu yang berasal dari Alqur'an dan hadis atau Islam budaya berupa ungkapan para sahabat, perkataan ulama, atau perkataan cendekiawan muslim bahkan mungkin saja budaya umat Islam.

Sebagaimana contoh dalam ayat al-Qur'an dalam surah al-Hasyr/59:18

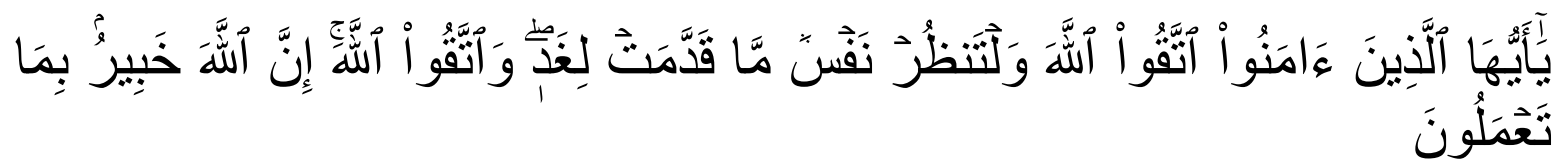

(18) "Hai orang-orang yang beriman, bertakwalah kepada Allah dan hendaklah setiap orang memperhatikan apa yang telah dilakukannya dihari esok (akhirat); dan bertakwalah kepada Allah, sungguh Allah Maha Mengetahui apa yang kamu lakukan”. (QS. al-Hasyr/59:18)

Menurut Abu al-Fida'Ismail Ibn Umar dalam Ibnu Katsir bahwa yang

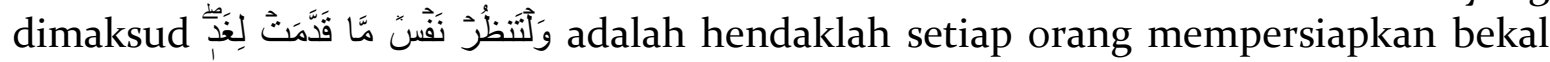
untuk akhirat, hari dimana hamba bertemu dengan Tuhan-Nya. ${ }^{9}$

Dalam ayat ini memberikan peringatan terhadap orang yang beriman tentang bagaimana memikirkan masa depan meraka. Masa depan dalam manajemen dituangkan dalam istilah yang jelas dan sistematis disebut perencanaan (planning). Sesuatu yang direncakan menjadi pengarah bagi setiap kegiatan, target dan berdampak pada hasilnya nanti, sehingga kegiatan apapun dapat dikerjakan dengan tertib.

\section{Fungsi Manajemen Pendidikan Islam}

Manajemen mempunyai fungsi-fungsi tertentu dan bersifat tidak berwujud (intangible), hal tersebut tidak bisa dilihat, tetapi hasilnya dapat dirasakan, yakni pekerjaan dengan output yang baik, serta ada kepuasan sendiri, produk dan servisnya lebih baik. ${ }^{10}$

\footnotetext{
${ }^{8}$ (Mujamil Qomar, 2012, h. 6)

${ }^{9}$ (Damasqa, A. F, h. 88)

${ }^{10}$ (George R. Terry, 2013, h. 9)
} 
Para ahli berbeda pendapat dalam merumuskan fungsi manajemen, namun pada intinya terdapat beberapa persamaan, berikut pendapat para ahli manajemen tentang fungsi-fungsi manajemen, diantaranya menurut Skinner, "fungsi manajemen meliputi planning, organizing, staffing, directing, dan controlling. Steppen P. Robbin menyebutkan fungsi manajemen meliputi planning, organizing, leading, dan controlling". Fathurrahman (2014, h. 26). Dari uraian dari para ahli, para pakar mengabstraksikan proses manajemen menjadi empat proses, yaitu planning, organizing, actuating, dan controlling (POAC).

Namun dalam hal ini, para pakar manajemen pendidikan Islam memutuskan proses manajemen pendidikan Islam menjadi perencanaan pendidikan Islam, pengorganisasian pendidikan Islam, pelaksanaan pendidikan Islam, dan pengawasan pendidikan Islam. ${ }^{11}$

Pertama, perencanaan dalam manajemen pendidikan Islam harus dilakukan secara teliti, sebagaimana Rasulullah selalu melakukan perencanaan secara teliti. Mengenai ketelitian dalam membuat perencanaan dalam mengambil Tindakan banyak terdapat di dalam Alqur'an baik secara jelas atau secara sindiran. Sebagaimana Allah SWT berfirman dalam QS. Al-Maidah/5:92.

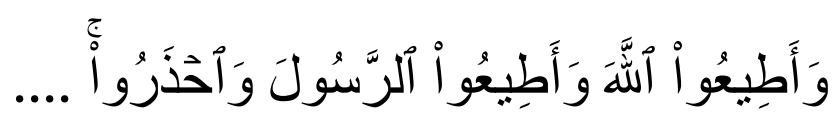

(92) "Dan taatlah kalian kepada Allah dan kepada Rasul-(Nya) dan berhati-hatilah (peliharah diri kamu dari kesalahan)”. (QS. Al-Maidah/5:92).

Merencanakan segala sesuatu secara baik dapat melahirkan keyakinan yang berdampak pada perbuatan yang sesuai dengan aturan serta bermanfaat, sehingga melakukan suatu perencanaan sangatlah diperlukan untuk menentukan arah masa depan suatu pendidikan termasuk di dalamnya pendidikan Islam. Meningkatkan mutu pendidikan harus disertai perencanaan berupa prioritas utama dalam melaksanakan pendidikan berjalan secara efektif, dengan melibatkan semua unsur yang terlibat dalam proses pendidikan, masyarakat, dan bahkan peserta didik. Penetapaan tujuan sebagai garis pengarahan dan sebagai evaluasi terhadap pelaksanaan dan hasil pendidikan, serta formulasi prosedur sebagai tahap rencana tindakan serta penyerahan tanggung jawab kepada individu dan kelompok kerja.

Kedua, pengorganisasian yang dilaksanakan dalam manajemen adalah bagian dari kegiatan dasar untuk mengelola dan mengatur seluruh sumber daya yang dibutuhkan termasuk unsur di dalamnya manusia, sehingga apa yang dilakukan dapat terselesaikan dengan baik. Dari beberapa sumber daya yang terpenting adaalah unsur manusia karena tugas mereka saling berkaitan dalam pengergonisasian. ${ }^{12}$

Konsep organizing diatas hampir sama dengan pendapat Ahmad bin Daud alAsy'ari dalam kitab Muqaddimah fi al-Idarah al-Islamiyah mengatakan bahwa pengerganisasian itu merupakan sekumpulan manusia bekerja sama dan saling tolong menolong dalam menyelesaaikan tugas dan pekerjaan sebagaimana struktur

\footnotetext{
${ }^{11}$ (Fathurrahman, 2014, h. 28)

${ }^{12}$ (George R. Terry, 2013, h. 73)
} 
yang telah ditentukan. Setiap orang dalam suatu organisasi akan melaksanakan tugasnya masing-masing disertai hak dan kewajibannya sesuai dengan keahlian dan kemampuannya dalam mencapai tujuan yang telah ditentukan. ${ }^{13}$.

Melihat dari defenisi tersebut bahwa pengorganisasian tersebut tidak terlepas dari manusia baik itu sendiri maupun kelompok yang mengerjakan tugasnya sesuai mekanisme sehingga dapat bekerja secara efektif dan bermanfaat bagi proporsinya masing-masing, hal tersebut dapat menjamin organisasi lembaga pendidikan Islam berjalan baik. Firman Allah SWT dalam QS. al-An’am/6:132

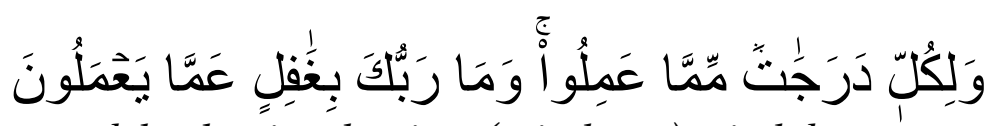

(132) "Dan setiap orang memperoleh derajat-derajat (seimbang) tindakan yang dilakukannyanya. Dan Tuhan kamu tidak lengah dari apa yang mereka lakukan.” (QS. al-An'am/6:132).

Ayat di atas secara jelas menjelaskan bahwa manusia dalam prakteknya berkarya sesuai keterampilan masing-masing, baik itu berupa ilmu yang mereka miliki ataupun pengalaman yang nantinya akan menjadikan mereka pada posisi yang tertentu.

Ketiga, fungsi manajemen selanjutnya adalah pelaksanaan dengan merealisasikan kegiatan yang telah direncana disusun menjadi tindakan nyata dalam rangka mencapai tujuan secara efektif dan efisien, sehingga setiap pelaksanaan dalam organisasi seharusnya memiliki kekuatan yang mantap dan meyakinkan sebab jika tidak memiliki hal tersebut, maka proses pendidikan dan pengajaran yang rencanakaan akan sulit terealisasikan. ${ }^{14}$. Diantara beberapa fungsi manajemen, fungsi pelaksanaan (actuating) yang sangat penting. Fungsi perencanaan dan pengorganisasian lebih banyak berkaitan dengan aspek-aspek abstrak dalam manajemen, sedangkan fungsi actuating berkaitan langsung dengan sumber daya dalam organisasi dengan lebih menekankan pada kegiatan, sehingga melalui fungsi pelaksanaan ini yang dilakukan secara efektif dan efisien, diharapkan memberikan konstribusi dalam meningkatkan kualitas pendidikan secara menyeluruh.

Dalam hal pelaksanaan, peran yang sangat penting adalah pimpinan karena akan banyak berkaitan dengan manusia sebagai subjek kegiatan, sehingga secanggih apapun peralatan yang digunakan jika tidak disertai dukungan manusia khususnya pimpinan maka akan sia-sia.

Dalam bahasa Arab, kata "actuating” diartikan “al-taujih" yaitu mengarahkan. 15. Kata menggerakkan atau mengarahkan sumber daya manusia disebutkan di beberapa ayat dalam Alqur'an untuk mencapai tujuan bersama, seperti "tabsyir" (memberi kabar bahagia) dan, "Indzar" (memberi peringatan atau teguran) sebagaimana dalam QS. al-Baqarah/2:213, Allah SWT menunjuk para Nabi menuntun dan mengarahkan umatnya menuju jalan yang telah ditetapkan oleh Allah SWT dengan memerikan kabar gembira dan peringatan kepada hambanya,

\footnotetext{
${ }^{13}$ A. b Al-Asy'ary, Muaqaddimah Fi Al-Idarah Al-Islamiyah, 2005.

${ }^{14}$ (E Mulyasa, 2017, h. 27)

${ }^{15}$ (Al-Asy'ary, 2005, h. 273)
} 
"dakwah" (mengajak atau menyeru) sebagaimana dalam QS. al-Nahl/16: 125, "tarbiyah" (bimbingan) sebagaimana dalam QS. al-Isra'/17: 24, dan terakhir adalah "irsyad" pengarahan dalam hal ini adalah pengarahan kepada kegiatan yang positif.

Keempat, Pengawasan atau controlling berasal dari bahasa Perancis yaitu "contre"berarti melawan. Sedangkan secara etimologis sering diterjemahkan dengan pengendalian atau pengawasan. Pengawasan pada dasarnya merupakan ukuran tampilan yang nyata terhadap perencanaan dengan mendeteksi penyebaran secara signifikan antara hasil dan harapan, dan mengidentifikasi tindakan penyebaran tersebut, hingga dapat mengambil tindakan perbaikan. Saiful Sagala dalam bukunya mengatakan bahwa pengawasan meliputi pemeriksaan kesesuaian terhadap apa yang direncanakan, intruksi yang dikeluarkan, serta prinsip yang telah diterapkan. ${ }^{16}$. Berhubungan dengan pengawasan Allah SWT berfirman dalam QS al-Infitar/82: 1012

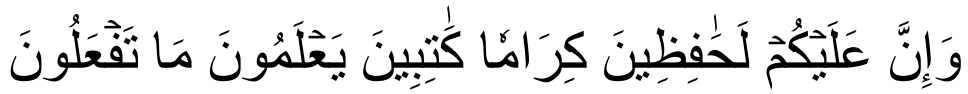

(10) "Sungguh bagi kalian ada malaikat yang mengawasimu, (11) yang mulia dan mencatat segala pekerjaanmu itu), (12) mereka mengetahui apa yang kalian kerjakan." (QS al-Infitar/82: 10-12).

Pengendalian tersebut dapat dilakukan dengan tahapan yang telah ditentukan bedasarkan perencanaan yang telah disusun sebelumnya serta tidak bertentangan dengan syariat Islam. Contoh dari pengendalian ini adalah perbuatan Umar bin Khattab sejak diangkat jadi khalifah, beliau melakukan proses kontrol sesuai dalam manajemen, sehingga dalam hal ini Umar bin Khattab dianggap sebagai bapak pendiri administrasi modern yang telah mempraktekkan proses pengendalian lima belas abad yang lalu.

\section{Simpulan}

Fungsi manajemen terhadap pendidikan Islam sangatlah penting untuk mencapai tujuan pendidikan Islam secara efektif dan efesien dan mendapatkan hasil sesuai dengan impian dan tujuan dari Lembaga Pendidikan Islam. Para pakar berbeda dalam merumuskan proses manajemen, namun pada intinya terdapat beberapa persamaan yang mencakup empat fungsi manajeman yang harus diperhatikan, yaitu perencanaan pendidikan Islam, pengorganisasian pendidikan Islam, pelaksanaan pendidikan Islam, dan pengawasan pendidikan Islam. Dengan memperhatikan keempat fungsi manajemen pendidikan di atas, diharapkan dapat meningkatkan kualitas pendidikan secara keseluruhan.

Penelitian ini diharapkan berimplikasi terhadap para pengelola lembaga pendidikan dapat memberikan sumbangsi baik yang substansial dan konstruktif bagi pendidik, mahasiswa dan semua pembaca serta bisa menjadi rujukan dalam penulisan selanjutnya, dan penulis sadar bahwa penulisan ini penuh dengan kekurangan diharapkan penelitian selajutmya dapat menyempurnakannya.

\footnotetext{
${ }^{16}$ (Sagala, 2017, h. 65)
} 


\section{Besse Ruhaya}

Fungsi Manajemen teradap......

\section{DAFTAR PUSTAKA}

Al-Asy'ary, A. b. Muaqaddimah Fi Al-Idarah Al-Islamiyah, 2005.

Damasqa, A. a.-F. Tafsir Al-Qur'an Adzim. Mauqi'ul al-Islam: Sofwer Maktabah Syamilah, n.d.

Departemen Pendidikan dan Kebudayaan. Kamus Besar Bahasa Indonesia. Jakarta: Balai Pustaka, 2005.

E Mulyasa. Manajemen Berbasis Sekolah, Konsep, Strategi, Dan Implementasi. Bandung: Remaja Rosdakarya, 2017.

Ernie Tisnawati Sule, Kurniawan Saefullah. Pengantar Manajemen. Jakarta: Kencana Prenada Media Grup, 2015.

Fathurrahman. Esensi Manajemen Pendididikan Islam. Yogyakarta: Teras, 2014.

George R. Terry. Prinsip-Prinsip Manajemen. Jakarta: Bumi Aksara, 2013.

John M. Echols dan Hassan Shadily. An English-Indonesia Dictionary. Jakarta: Gramedia, 2013.

Maujud, Fathul. "Implementasi Fungsi-Fungsi Manajemen Dalam Lembaga Pendidikan Islam (Studi Kasus Pengelolaan Madrasah Ibtidaiyah Islahul Muta'allim Pagutan)." JURNAL PENELITIAN KEISLAMAN, 2018. https://doi.org/10.20414/jpk.v14i1.490.

Mujamil Qomar. Manajemen Pendidikan Islam: Strategi Baru Pengelolaan Pendidikan Islam. Jakarta: Erlangga, 2012.

Republik Indonesia. Undang-Undang Sistem Pendidikan Nasional Nomor 20 Tahun 2003. Jakarta: Sinar Grafika Offset, 2019.

Sagala, Syaiful. Konsep Dan Makna Pembelajaran Untuk Membantu Memecahkan Problematika Belajar Dan Mengajar. Bandung, 2017.

Usman, Husaini. Manajemen: Teori Praktik Dan Riset Pendidikan. Jakarta: PT Bumi Aksara, 2008. 